\title{
PARÁZSLÓ MUNKAERŐPIAC
}

\author{
(A Changing Labour Market)
}

\section{SCHWERTNER JÁNOS}

\author{
Átalakuló munkaerôpiac
}

A negyvenes évek végétõl kezdõdõen a hazai foglalkoztatáspolitika a teljes foglalkoztatást vallotta magáénak. Ezt a célt - a munkaerômérlegek, a munkaerõforgalmi statisztikák alapján ma már tudjuk - teljes mértékben soha sem sikerült megvalósítania, de a közgazdasági szabályozók folyamatos alakításával el lehetett érni, hogy nyílt munkanélküliségrôl 1988-ig nem beszélhettünk.

A nyolcvanas évek végén még sikerült a munkanélküliséget mint lokálisan jelentkezõ, egyes speciális térségekhez kapcsolódó strukturális jelenségként feltüntetni. Ezzel együtt 1989. január 1-jével bevezetésre került a munkanélküli ellátási rendszer mára már többször módosított intézménye, azaz a munkanélküliség nem volt tovább tagadható.

A munkaerôpiaci szervezetek mũködésének feltételeit, az ellátási rendszer szabályait, továbbá a munkaerôpiaci érdekegyeztetés formáit az 1991. évi IV. törvény rögzítette, majd elkezdôdött az állami munkaerôpiaci ellátó szervezet kiépítése. Létrejött az Országos Munkaügyi Központ 19 megyei dekoncentrált központja, továbbá a központok kirendeltségei. A kirendeltségek illetékességi területe egy-egy munkaerôpiaci vonzáskörzetnek fogható fel.

A munkanélküliek regisztrálásának bevezetését követôen másfél éven belül a munkaerôpiac korábbi keresleti többlete - állománycsoportonként és területileg idôben eltérõen - kínálati többletbe csapott át. A munkaerópiaci folyamatokra - a jelentõs változások ellenére - azóta is tartósan ez a tendencia a jellemzó, a kereslet töredéke a kínálatnak. A magas munkanélküliség azonban elterelte figyelmünket a foglalkoztatási struktúra idõközbeni jelentôs átalakulásáról, továbbá arról a tényrôl, hogy 1993. februảrjától egyszerre csökken a munkanélküliek, valamint a foglalkoztatottak száma.

\section{A foglalkoztatási szerkezet változása}

A nemzetgazdaságban foglalkoztatottak száma 1989 és 1993 között 25\%-kal, egymillió 352 ezer fôvel csökkent. A gazdasági visszaesésben meghatározó mezógazdaságban és erdõgazdálkodásban $62 \%$-os, az iparban $29 \%$-os volt a létszámvesztés. Az építóipar- 
ban foglalkoztatottak száma $29 \%$-kal esett vissza, míg a közlekedésben $23 \%$-kal dolgoznak kevesebben. A nem anyagi ágakban foglalkoztatottak száma szerényebb mértékben, $3 \%$-kal csökkent, a kereskedelemben foglalkoztatottaké pedig lényegében változatlan maradt.

Ilyen módon a foglalkoztatás csökkenése mellett átrendezôdött a három nagy foglalkoztatási szektor aránya is: a primer szektor (mezôgazdaság és erdôgazdálkodás) aránya 18\%-ról 10\%-ra, a szekunder szektor (ipar és építôipar) aránya 37\%-ról 35\%-ra csökkent, míg a tercier szektorban (a szélesen értelmezett szolgáltatásban) a foglalkoztatottak aránya $45 \%$-ról $55 \%$-ra nốtt.

A gazdasági szektorok arányaiban történt változások iránya közelíti Magyarországot a fejlett piacgazdaságokhoz, problémát alapvetôen a változások bekövetkezésének gyorsasága, módja jelent, történetesen, hogy mindezen pozitív változások egy mélyülố recesszió mellett zajlottak le.

A foglalkoztatottak számának csökkenésével egyidôben az elmúlt négy év alatt dinamikusan nôtt a gazdálkodó szervezetek száma. Legnagyobb mértékben a nem jogi személyiségũ gazdasági szervezetek száma gyarapodott, 1991 és 1993 között számuk csaknem megháromszorozódott. A jogi személyiségü gazdasági szervezetek száma két és félszeresére nốtt. 1993 végén már közel 700 ezer egyéni vállalkozót tartottak nyilván. A 20 fô alatti létszámú szervezeteknél és az egyéni vállalkozásoknál dolgozók ma már a foglalkoztatottak több mint egyharmadát képviselik, ugyanakkor 1993-ban még a 300 fốt meghaladó létszámú közép- és nagyvállalatoknál dolgozott a foglalkoztatottak több mint fele. A munkaerópiac keresleti oldalának differenciálódása a korábban országosan többé-kevésbé egységes munkaerôpiacot is széttördelte.

\section{A Dél-Dunántúl foglalkoztatási helyzete}

A hazai munkanélküliség kezdetétôl, 1988-tól a Dél-Dunántúl egyes térségeiben ismert az állástalanok elhelyezkedési nehézsége. A gazdasági szerkezetváltáshoz kapcsolódó munkahely bezárások Baranya megyében 1989-tôl súlyos foglalkoztatási helyzetet teremtettek. A felhagyott bányászkodással érintett térséget a kormány ,,kritikus térséggé" nyilvánította, amiáltal intenzív foglalkoztatáspolitikai támogatásban részesült.

Az országosan gyorsuló munkanélküliség mellett a rendelkezésre álló erôforrások szũkössége 1990-tôl már nem engedte meg újabb kritikus térségek kijelölését, továbbá a korábban kialakított térségek speciális támogatási programjait is fokozatosan kifuttatta a munkaügyi kormányzat.

A foglalkoztatottak számának minden korábbit felülmúló ütemũ csökkenése jellemezte a Dunántúl déli megyéit is. A négy dél-dunántúli megyében (Baranya, Somogy, Tolna, Zala) az 1990. évi népszámlálás idején az ország teljes népességének $12,8 \%$-a, azaz 1323429 fổ élt. Közülük - az összeírások tanúsága szerint - 573693 fố volt aktív 
keresô, továbbá 13222 fố magát munkanélkülinek vallót és 1798 elsố ízben elhelyezkedni kívánót írtak össze. Így az aktív keresốk munkanélküliekkel együtt értelmezett teljes száma a népszámlálás idōpontjában 588713 fô volt.

Az aktív keresốk számának változásáról - újabb népszámlálásig - információink nincsenek, de a gazdaságilag aktív népesség számát, amely egyszerre tartalmazza a foglalkoztatottakat és a regisztrált munkanélkülieket, a KSH megyei szinten egy évre visszamenôleg az országos adat alapján becsléssel állapítja meg. ${ }^{\prime}$ A népszámlálást követố három év alatt a gazdaságilag aktív népesség száma országosan közel 300 ezer fôvel, a Dél-Dunántúlon is több mint $7 \%$-kal, három év alatt 50 ezer fỗvel csökkent ( 1 . táblázat). Mindeközben a munkanélküliség a Dél-Dunántúlon is dinamikusan növekedett, az 1991 év eleji 15 ezer fôrôl 1993 januárjában 82 ezer före, majd év közben némileg csökkent, december végén kevéssel haladta meg a 78 ezer fôs szintet.

\section{TÁBLÁZAT}

A gazdaságilag aktiv népesség száma megyénként

(lakóhely szerint, ezer fố)

(Number of the economically active population in the counties

[place of residence, in thousand persons])

\begin{tabular}{lcccc}
\hline Megye & 1991 & 1992 & 1993 & $\begin{array}{c}\text { Index (\%) } \\
1993 / 1991 .\end{array}$ \\
\hline Baranya & 212,3 & 208,4 & 204,5 & 96,3 \\
Somogy & 173,4 & 173,0 & 155,8 & 89,9 \\
Tolna & 135,7 & 129,2 & 121,0 & 89,2 \\
Zala & 160,8 & 157,3 & 151,2 & 94,0 \\
\hline Dél-Dunántúl & 682,2 & 667,9 & 632,5 & 92,7 \\
\hline Ország összesen: & 5400,2 & 5202,2 & 5015,0 & 92,9 \\
\hline
\end{tabular}

Forrás: KSH becslés.

\section{Kereslet és kínálat a munkaerốpiacon}

\section{A munkanélküliek szakmák szerinti megoszlása}

A munkaügyi kirendeltségeken a munkanélküli által keresett állás FEOR száma szerint nyilvántartják a munkanélküliek elsố helyen megjelölt álláshely igényeit. Természetesen a regisztráció során elképzelhetô, hogy egy-egy ügyfél olyan szakmát jelöl meg, amit nem képes ellátni, esetleg fordítva, olyat aminél kvalifikáltabb tevékenység ellátására is képes lenne. Összességében azonban a válaszok többsége mögött a valós foglalkoztatási igény szerepel. 
A munkanélküliség kezdeti idôszakától a fizikai foglalkozásokkal rendelkezôk alkotják az állást keresõk négyötödét. Közülük is meghatározó arányt képviselnek a szakképzetlenek körében azok, akik csak segédmunkát (közel $11 \%$-a a teljes állománynak), illetve egyéb fizikai foglalkozást $(9,8 \%)$ kívánnak ellátni. A szakmával rendelkezôk közül a legtöbb álláskeresô a géplakatos, tehergépkocsivezetô, kômüves, gépjármũszereló, villanyszerelô, festô és mázoló, élelmiszer és egyéb bolti eladó, esztergályos, könyvelô, hegesztố szakmát képviseli. A tíz legkeresettebb szakma közül csupán egy, a könyveló, fôkönyvelô tartozik a szellemi tevékenységek körébe. Országosan a tíz legkeresettebb szakmát közel 106 ezer fổ kereste, a regisztrált munkanélküli állomány 16\%-a.

Viszonylag szerény számúnak tûnik az egyértelmũen mezôgazdasági szakmát keresốk köre (traktoros, növénytermesztố, mezốgazdasági gépszerelô, baromfitenyésztỗ, állatgondozó, szőlổtermesztô, sertésgondozó, dísznövénytermesztô, fakitermelổ stb.), számuk alig éri el a 32 ezer fốt, arányuk 4,6\%. A mezổgazdaságban állásukat elveszítók többségükben nem kifejezetten mezôggazdasági tevékenységet végzổk (segédmunkás, ốr, villanyszerelố, gépkocsivezetố stb.) körébôl kerültek ki.

Az 1993 nyarán a Dél-Dunántúlon regisztrált munkanélküliek (79560fô) közül 21815 fổ $(27 \%)$ - az országos mértéknél kevéssel magasabb arányban - tartozott a szakmával nem rendelkezó fizikai foglalkozást, és 3029 fô $(3,8 \%)$ a szakmával nem rendelkezô szellemi foglalkozást keresôk közé.

Az állást keresôk körében a Dél-Dunántúlon az országos átlagnál kevésbé erôs a koncentráció. A teljes állomány 14,7\%-a kívánt a tíz legkeresettebb szakmában elhelyezkedni, míg az országos igényekkel szemben itt egyes szakmák keresettebbek. ${ }^{2}$

A Dél-Dunántúlon belül a speciális szakmáknál jelentôs eltérés mutatkozik a megyék között, például az országosan regisztrált kesztyũs munkanélküliek fele Baranyában él, míg Zalában egy sem. Fordított a helyzet a kép- és elektroncsố gyártás esetében.

A regisztrált munkanélküliek között az egyértelmũen mezô- és erdõgazdasági munkát keresôk száma 4667 fố volt, arányuk 5,9\%, tehát magasabb az országos átlagnál.

\section{Alláshelyek}

Az álláshelyek száma 1993 tavaszán jelentôsen bõvült. Ez volt a munkanélküliség létezése óta az elsô év, amikor a munkahelyek választékában a szezonális hatás megjelent.

Országosan 1993 júniusában 30771 betöltetlen álláshelyet tartottak nyilván, vagyis az elôzzô év hasonló idôszakához képest 5425 álláshellyel többet, de 1993 májusához képest 9555-nel kevesebbet. Az ismert álláshelyek közül 16,8\%-ot, az itt éló állástalanok arányánál 4,7\%-kal többet, a Dél-Dunántúlon hirdették meg. Így az állásajánlatok aránya a Dél-Dunántúlon kedvezốbb helyzetet mutatott az országos átlagnál. Itt minden 
15. álláskeresốre jutott egy betöltetlen álláshely, míg országosan csak minden 21 . munkanélkülinek lehetett volna optimális esetben elhelyezkedési esélye.

A keresett FEOR csoportok közül a legnagyobb létszámú, az egyéb fizikai és a segédmunkás csoport (8066 fô, 16,2\%) a Dél-Dunántúlon (1990 fô, 38,6\%) az országos szintet messze meghaladó nagyságú.

A bejelentett betöltetlen álláshelyek $83,9 \%$-ára fizikai foglalkozásút kerestek, 42,4\%ban szakmunkásokat, 27,2\%-ban betanított munkást és 14,3\%-ban segêdmunkást (2. táblázat).

\section{TÁBLÁZAT}

A regisztrált munkanélküliek és a bejelentett álláshelyek megoszlása a Dél-Dunántúlon állománycsoportok szerint (1993. június)

(Breakdown of registered unemployed and declared jobs by staff groups in South Transdanubia [(June 1993])

\begin{tabular}{lcccccc}
\hline Idṍpont & $\begin{array}{c}\text { Szak- } \\
\text { munkás }\end{array}$ & $\begin{array}{c}\text { Betanitott } \\
\text { munkás }\end{array}$ & $\begin{array}{c}\text { Segéd- } \\
\text { munkás }\end{array}$ & $\begin{array}{c}\text { Fizikai } \\
\text { foglalkozású } \\
\text { összesen }\end{array}$ & $\begin{array}{c}\text { Szellemi } \\
\text { foglał- } \\
\text { kozású }\end{array}$ & Összesen \\
\hline \multicolumn{7}{c}{ A regisztrált munkanélküliek megoszlása } \\
1992. VI. & 33,3 & 24,3 & 26,3 & 83,9 & 16,1 & 100,0 \\
1992. XII. & 35,0 & 23,4 & 25,2 & 83,6 & 15,4 & 100,0 \\
1993. VI. & 34,3 & 23,4 & 26,5 & 83,2 & 16,8 & 100,0 \\
& \multicolumn{7}{c}{ A bejelentett álláshelyek megoszlása } \\
1992. VI. & 38,0 & 31,9 & 17,1 & 87,0 & 13,0 & 100,0 \\
1992. XII. & 47,3 & 25,0 & 10,9 & 83,2 & 16,8 & 100,0 \\
1993. VI. & 42,4 & 27,2 & 14,3 & 83,9 & 16,1 & 100,0 \\
\hline
\end{tabular}

Forrás: OMK Statisztika.

Arányaiban az álláshelykínálat többé-kevésbé megfelelne a keresletnek (3. táblázat), kirivó eltérés a segédmunkások vonatkozásában van, akik még az álláshelyek nagyobb számú növekedése esetén is csak részben jutnának munkalehetôséghez. A szakmunkások esetében a mai lanyha kereslet mellett is érzékelhetõ a jelentõs strukturális eltérés a kereslet-kínálat között.

A mezõgazdasági szakmák gyakorlatilag hiányoznak a keresletbôl, ebben az ágazatban mindössze kilenc új álláshelyet hirdettek meg.

A hazai munkaerópiac néhány szakmát és tevékenységcsoportot leszámítva kínálati piac. A megnyilvánuló lanyha kereslet többnyire azon foglalkozási csoportoknál jelentkezik, ahol egyébként is nagyobb számban találunk regisztrált munkanélkülieket. 


\section{TÁBLÁZAT}

A Dél-Dunántúlon megnyilvánuló munkaerổpiaci kereslet és kinálat (1993. június) (Labour market demand and supply in South Transdanubia [June 1993])

\begin{tabular}{rlrr}
\hline Kereslet & \multicolumn{1}{c}{ Tevékenység } & Kinálat & $\begin{array}{c}\text { Az egy állásra } \\
\text { jutó pályázók száma }\end{array}$ \\
\hline 1438 & egyéb fizikai foglalkozás & 7923 & 5,5 \\
552 & segédmunkás & 10058 & 18,2 \\
325 & szabó, varrónó & 638 & 2,0 \\
214 & ügynök & - & - \\
187 & kômũves & 339 & 7,2 \\
183 & textilkonfekcionáló & 558 & 3,0 \\
154 & takarító & 2227 & 14,5 \\
150 & tartósítóipari munkás & 176 & 1,2 \\
142 & felszolgáló & 606 & 4,3 \\
102 & szakács & 381 & 3,7 \\
80 & villamosipari technikus & 56 & 0,7 \\
75 & cipöfelsórész-készítõ & 332 & 4,4 \\
64 & élelmiszerbolti eladó & 1071 & 16,7 \\
52 & egyéb bolti eladó & 734 & 14,1 \\
52 & tehergépkocsivezetõ & 2127 & 40,9 \\
50 & ács-állványozó & 309 & 6,2 \\
46 & asztalos & 583 & 12,7 \\
\hline
\end{tabular}

Forrás: OMK Statisztika alapján.

Az azonos szakmáknál egyszerre megnyilvánuló kereslet és kínálat jelzi, hogy a munka ellátásával kapcsolatban olyan új minôségi igényeket is támasztanak a munkaadók, amelyek korábban nem, vagy csak részlegesen fogalmazódtak meg és statisztikai adatokkal nehezen megfoghatók. A szakmával rendelkezõo, de a többlet elvárásoknak megfelelni nem tudók csoportja reménytelenül várakozik új álláshelyre.

A munkavállalók ezen csoportja döntôen mentális és szociális okok miatt nem képes visszatérni a munkaerốpiacra, így a foglalkoztatáspolitikai eszközök számukra igénybevehetetlenek. E több százezres csoport tagjai közül egyre többen választják menekülésként az inaktív állapotot. Kényszerũségboól kivonulnak a munkaerốpiacról, ezzel csökkentve a népesség aktivítási szintjét. 


\section{A munkanélküliség}

\section{A munkanélküliség okai}

A hazai munkanélküliség számos összetevôbõl eredeztethetõ. A munkanélküliség szakirodalmában használt okcsoportokkal a hazai munkanélküliség csak részben jellemezhetỗ. Esetünkben nem egy-két év kedvezôttlen gazdasági hatásairól, piaci pozíciók átmeneti rosszabbodásáról van szó, hanem több évtized hibás gazdaság- és társadalompolitikájáról, aminek negatív jelenségei gyakorlatilag egyszerre törnek a felszínre (Lackó M. 1993).

Az alapvetô okok mind a munkaerõ, mind a gazdaság oldaláról a piac korábbi hiányában keresendôk. Nem véletlen, hogy a munkanélküliség elsõ jelei a közgazdasági szabályozó rendszerek 80-as évekbeli változásához kapcsolódnak. Miután például a gazdasági hatékonyság, a bérköltség a korábbi gazdaságpolitika retorikai szintjéröl a valóság talajára hullottak, megjelent a felesleges, elhelyezkedni nem tudó, álását elveszítõ munkaerô. Ezt követôen idôrendben keresleti oldalról az alábbi tényezốk növelték a munkanélküliség mértékét:

- ipari strukturális feszültségek (kitermelô ipar, nehézipar stb.);

- a KGST-piacok elvesztése;

- a mezôgazdasági támogatási rendszer leépítése;

- a fejlett országokat sújtó recesszióból adódó piacvesztés;

- a belsô piac zsugorodása;

- a cégek átalakulása, átstrukturálódása;

- a magánosítás, új tulajdonosi szerkezet;

- az ország geopolitikai helyzetének változása.

Kínálati oldalon mindeközben a munkaerô iskolázottsága, szaktudása, idegennyelv ismerete elmaradt az európai színvonalú gazdaságok igényeitôl, így a munkaerôpiacon az elmúlt négy év alatt felhalmozódott egy szakmával nem rendelkezô, iskolázatlan 200-300 ezres tömeg, mely számára a tartós munkahely hosszabb távon is csak remény marad. A kínálati oldal feszültségeit tovább élezte az évtized elején a korábbinál nagyobb mértékben a munkaerópiacra belépõ pályakezdốk száma.

A munkanélküliség tömeges méretéhez és gyors növekedéséhez országosan, valamint a Dél-Dunántúlon is hozzájárult az infrastruktúra fejletlensége, a városok, urbanizált térségek relatív hiánya, az intézmények túlzott települési koncentrációja, a népesség külsõ és belsô migrációjának alacsony színvonala. Magyarországon az aktív, de állást keresố társadalom döntô része lakóhelyén vagy annak szűk kömyezetében keresi boldogulását. Az útiköltségek jelentốs drágulása miatt a korábbi munkaerôpiaci vonzáskörzetek ,,összezsugorodtak", s a települések egyre nagyobb hányadából közgazdaságilag már nem racionális a munkaerô ingázása. A lakóhely közelében pedig új munkahelyek 
kialakításához általában hiányzik a megfelelố minóségũ infrastruktúra, valamint a megfelelõ mennyiségũ tôke.

A munkanélküliség hatékony kezelése a világban sehol sem volt sikeres a munkaerõ jelentôs mobilizálása nélkül. A drága aktív eszközökkel érintett munkanélküliek száma Nyugat-Európában - a két olajválság után - töredéke volt a munkavállalási céllal lakóhelyet változtatóknak. A magyarországi munkanélküliség nagy kérdése, hogy mikor és milyen mennyiségben indul el a munkaerô a kedvezôbb munka- és életfeltételek irányába. Egy esetleges, a közeljövốben megkezdõdô jelentốs belsố migráció fogadására pillanatnyilag mind a társadalom, mind pedig a politika felkészületlen. A mai szintnél jelentôsebb belsô vándorlásnál a Dél-Dunántúl egyszerre lenne munkaerô kibocsátó és egyes munkaerôpiaci körzeteiben munkaeroót befogadó térség, amiáltal tovább fokozódnának a régió jelenleg is meglévõ térségi különbségei.

\section{A munkanélküliség mérése}

A munkanélküliség területi különbségeinél két adatforrásra, az Országos Munkaügyi Központ regiszter bázisú statisztikájára, valamint a KSH munkaerô-felvételére támaszkodhatunk. Az állást keresốk teljes körének regisztrálása az 1989. év elejétôl biztosított, a törvényi szabályozás feltételeit a már említett 1991. évi IV. törvény teremtette meg. A regisztrálás önkéntes, abban az ügyfél három motívum alapján érdekelt: egyrészt az álláshoz jutás és az ellátásban való részvétel, másrészt az aktív eszközökhöz való hozzájutás szempontjából.

1992-tổ a regisztrálást tovább ösztönzi az önkormányzatok részéról adható jövedelempótlásra való jogosultság megszerzése, aminek előfeltétele a munkaügyi szervezetnél történô jelentkezés.

A regiszter természetszerüleg nem tartalmaz minden munkanélkülit; belépési oldalon kimaradnak a regisztrálásra nem jogosultak, a passzívak, továbbá a munkaügyi hivatallal együttmüködésre nem hajlandók. Kilépési oldalon kihullanak a regiszterbôl az elhelyezkedetteken és inaktívvá válókon kívül a munkaügyi hivatallal tovább együttmüködni nem akarók, valamint a jövedelempótló-támogatásra nem jogosultak közül azok, akik nem reménykednek állásajánlatban, vagy aktív eszköz igénybevételében.

A regiszterbázisú munkanélküliségi nyilvántartás mellett 1992-tõl a KSH munkaerốfelvétele is szolgáltat adatokat a munkanélküliek számának összetételérổ. A munkaerốfelvétel a regisztrálástól eltéró, az ILO által elfogadott munkanélküli fogalommal dolgozik, ami összességében a regisztráltaknál szükebb kört tekint munkanélkülinek.

A munkaerô-felvételnél munkanélkülinek tekintendố, aki:

- az adott héten nem dolgozott;

- a kikérdezést megelôzố négy hétben aktívan keresett állást;

- munkába tudott volna állni, ha talált volna megfelelố munkát. 
Mivel területi adatok gyakorlatilag csak a regisztrálási adatokból állíthatók elô, ezért elemzésünkben elsôsorban a regiszterbázisú adatokra támaszkodunk, de figyelembe vesszük a KSH munkaerömérlegének adatait is.

\section{A munkanélküliek számának változása}

Az 1990. év eleji 24 ezer fổs munkanélküliség három év alatt 700 ezer fồsre növekedett (4. táblázat). A példátlanul gyors ütemũ növekedés hatására már 1991-ben a korábban csak bizonyos csoportokat érintổ munkanélküliség általánossá vált. Szakmánként és állománycsoportonként eltérô mértékben, de mindenkit veszélyeztetett az állástalanság, minden településben élt már munkanélküli. Ez a súlyos helyzet társadalomlélektani fordulatot jelentett; 1991. végétôl a társadalom többsége már szolidárissá vált a munkanélküliekkel.

\section{TÁBLÁZAT}

A regisztrált és ellátott munkanélküliek számának alakulása 1990-1993. év végén

(Change of the number of registered and treated unemployment at the end of 1990 and 1993)

\begin{tabular}{|c|c|c|c|c|c|c|c|c|}
\hline & \multicolumn{2}{|c|}{$\begin{array}{c}1990 \\
\text { december }\end{array}$} & \multicolumn{2}{|c|}{$\begin{array}{c}1991 \\
\text { december }\end{array}$} & \multicolumn{2}{|c|}{$\begin{array}{c}1992 \\
\text { december }\end{array}$} & \multicolumn{2}{|c|}{$\begin{array}{c}1993 \\
\text { december }\end{array}$} \\
\hline & $\begin{array}{l}\text { regiszt- } \\
\text { rált }\end{array}$ & $\begin{array}{l}\text { ellá- } \\
\text { tott* }\end{array}$ & $\begin{array}{l}\text { regiszt- } \\
\text { rált }\end{array}$ & $\begin{array}{l}\text { ellá- } \\
\text { tott }\end{array}$ & $\begin{array}{c}\text { regiszt- } \\
\text { rált }\end{array}$ & $\begin{array}{l}\text { ellá- } \\
\text { tott }\end{array}$ & $\begin{array}{l}\text { regiszt- } \\
\text { rált }\end{array}$ & $\begin{array}{l}\text { ellá- } \\
\text { tott }\end{array}$ \\
\hline Baranya & 3854 & 3620 & 18003 & 12919 & 28683 & 20817 & 25534 & 12817 \\
\hline Somogy & 3362 & 2694 & 13251 & 9997 & 19183 & 13483 & 19567 & 11441 \\
\hline Tolna & 2896 & 2539 & 12729 & 10279 & 19234 & 13837 & 17774 & 9958 \\
\hline Zala & 1840 & 1139 & 9630 & 7021 & 14991 & 10760 & 15609 & 9186 \\
\hline Dél-Dunántúl & 11952 & 9992 & 53613 & 40216 & 82091 & 58897 & 78484 & 43402 \\
\hline Többi megye & 64309 & 49052 & 323979 & 250174 & 519989 & 373993 & 490030 & 249669 \\
\hline Budapest & 3260 & 2649 & 28535 & 21687 & 60947 & 44072 & 63536 & 33547 \\
\hline Ország össz. & 79521 & 61693 & 406127 & 312077 & 663027 & 476962 & 632050 & 326618 \\
\hline
\end{tabular}

A munkanélküliség gyors növekedése óriási terhet rótt a munkaügyi apparátusra, ahol az ügyintézốk többsége csak ekkor tanulta a szakmát. Az ellátásban részesülők nagyrésze pedig a régi reflexek szerint a munkanélküli járadékot mint szociális juttatást fogta fel, amit minél hosszabb ideig érdemes használni. Részben ezzel a felfogással, részben 
az üres álláshelyek számának drámai mértékũ visszaesésével magyarázható, hogy a munkanélküliség - szemben a nemzetközi tapasztalatokkal - éveken át egyirányú beáramlási folyamat volt; ${ }^{3} 1992$ elsõ félévében az ellátási rendszerbôl kilépõk aránya nem haladta meg az·5\%-ot, ezért fokozatosan nốtt az ellátottak aránya és átlagos ellátási ideje.

A hazai munkanélküliség történetében a regisztrált munkanélküliek száma csúcspontját (705 ezer fỗ) 1993 februárjában érte el. Azóta e szám csökkenô tendenciát mutat. Az év végén a februári maximumnál 73 ezer fôvel, azaz 10\%-kal kevesebb munkanélkülit regisztráltak, ennek megfelelôen a munkanélküliségi ráta (munkanélküliek száma/gazdaságilag aktív népesség) 13,7\%-ról 12,1\%-ra esett vissza.

$\mathrm{Az}$ iskolai tanév befejezését követôen a munkaügyi központok összesen 78 ezer közép- és felsõfokú, valamint 10 ezer általános iskolai végzettségư fiatalt regisztráltak munkanélküliként. Ez a létszám az elôször munkaerớpiacra lépố ifjúság közel felét jelentette. Év végén a regisztrált pályakezdôk záró létszáma ( 63 ezer fố) a teljes regisztrált munkanélküli állomány egytizede volt.

Az ellátásban részesülôk harmada több mint egy éve kapja járadékát. Az ellátási rendszerbôl igényjogosultsági idejük lejárta miatt kikerültek közül 1993 végén 157 ezer fô részesült az önkormányzatok által folyósított jövedelempótló támogatásban.

A hazai munkanélküliség folyamatában meghatározó szerepe volt az 1993-as esztendổnek. Véget ért a munkanélküliség gyorsan növekvô, negatív társadalmi diffúziós jelenségnek minôsíthetỗ idôszaka. 1993-ban a munkaerổpiac feszültségei már nem fokozódtak tovább. A regisztrált munkanélküliek számának február óta tartó csökkenése több tényezổ együttes hatására vezethetổ vissza:

- Ezek közül kiemelkedố szerepe volt a járadékra való jogosultságukat már kimerítốk jelentốs számú bõvülésének. 1993-ban összesen 302 ezer fố igényjogosultsága járt le. Az Országos Munkaügyi Központ nyomon követéses vizsgálatának információi szerint (Lázár Gy. -Székely $J$. 1993) az ellátási idejüket kimerítettek több mint fele továbbra is regisztráltatja magát, mivel ez az elôfeltétele az önkormányzatok által nyújtott jövedelempótló támogatásnak, valamint a különbözõ munkaerôpiaci programokban való részvételnek. Mintegy $15 \%$-uk újra talált munkahelyet, további $15 \%$-uk inaktívvá (nyugdíjassá vagy eltartottá) vált, felhagyva a további álláskereséssel. A vizsgálat során az ellátásból kikerülớk közül 30-40 ezer fố már nem regisztráltatta magát, de szeretne elhelyezkedni, ezért továbbra is munkanélkülinek tekinthetô.

- A regisztrált munkanélküliek között nem tartják nyilván az aktív eszközökkel támogatott személyeket, akiknek a száma az 1993. év végén megközelítette a 90 ezer fốt. Kisebbik hányaduk korábban nem volt regisztrált munkanélküli, például azok akik átmeneti részmunkaidós támogatásban részesültek, míg nagyobbik részük például átképzésben résztvevốk, közhasznú munkások, korábban szerepeltek a regiszterben. 
- 1993 volt az elsõ év a munkaerôpiacon, amikor egyértelmủen érzékelhetỗ volt a szezonális foglalkoztatási hatás, különösen az idegenforgalmilag frekventált térségekben és a mezôgazdasági jellegũ körzetekben.

- Az elmúlt évben a munkahelyek 1991-92-ben még jellemzô tömeges mértékü megszünése mérséklődött. A munkáltatók által elổre bejelentett elbocsátások száma 1993-ban közel fele volt az egy évvel korábbinak. Eközben erổteljesen (16\%-kal) bổvült a gazdálkodó szervezetek és egyéni vállalkozások, azaz az újonnan létrehozott munkahelyek száma. 1993-ban minden hónapban magasabb volt a munkáltatók által bejelentett üres álláshelyek száma, mint az előzô év megfelelổ idôszakában, ami egyértelmũen a munkaerôpiaci kereslet élénkülését jelzi. Ennek ellenére az üres álláshelyek száma a legkedvezôbb hónapban sem érte el az ország összes álláshelyeinek $0,7-0,8 \%$-át.

\section{A munkanélküliség területi összefüggései}

Az elmúlt három év regiszter bázisú munkanélküliségi adatai alapján nyomon követhetjük a munkaerôpiaci körzetek és a településnagyság-csoportok alapján a munkanélküliség térben eltérô változásait, mozgásait. A hazai munkanélküliség területi különbségeit, folyamatát tanulınányozva öt olyan alapvetổ jelenséget îrhatunk le, amely bizonyíthatóan jellemzi Magyarország munkanélküliségi helyzetét.

\section{A nyugat-kelet dualizmus}

$\mathrm{Az}$ állástalanok területi megoszlása nem egyezik meg a népesség és azon belül az aktív korosztályok országon belüli elhelyezkedésével. Mig a fốvárosban és Pest megyében él a népesség 29 , az aktív keresõk $30 \%$-a, addig az összmunkanélküli állománynak csak $18 \%$-a lakik az ország központi területén. A népesség arányánál kisebb mértékben élnek munkanélküliek a Dunántúlon (a teljes munkanélküli állomány $28 \%$-a), amivel ellentétes a helyzet a Dunán inneni területeken, ahol a munkanélküliek $54 \%$-át regisztrálták, miközben az ország aktív keresổinek $40 \%$-a él ezen a területen (5. táblázat).

Kistérségi szinten a gazdasági-társadalmi feltételek jelentốs különbsége miatt a munkanélküliség mértékében is számottevổ, több mint tízszeres különbség érzékelhetố a legkedvezôbb, egyben legnyugatibb körzet (Sopron), valamint a legkedvezôtllenebb (Nagyecsed, Encs, Gönc) keleti munkaerôpiaci körzetek között (1.ábra).

A munkaeröpiaci vonzáskörzeteket földrajzi koordinátáik alapján nyugat-keleti irányba rendezve (Nemes Nagy J. 1993) kialakul a munkanélküliség mértéke szerinti nyugat-keleti lejtõ, amit a munkanélküliség mértékérôl készített kartogramok (Schwertner J. 1992) is visszaigazolnak. 
Schwertner János : Parázsló munkaerőpiac

Tér és Társadalom 8. évf. 1994/1-2. 59-82. p.

\section{1. ÁBRA}

A munkanélküliség alakulása

(Unemployment)
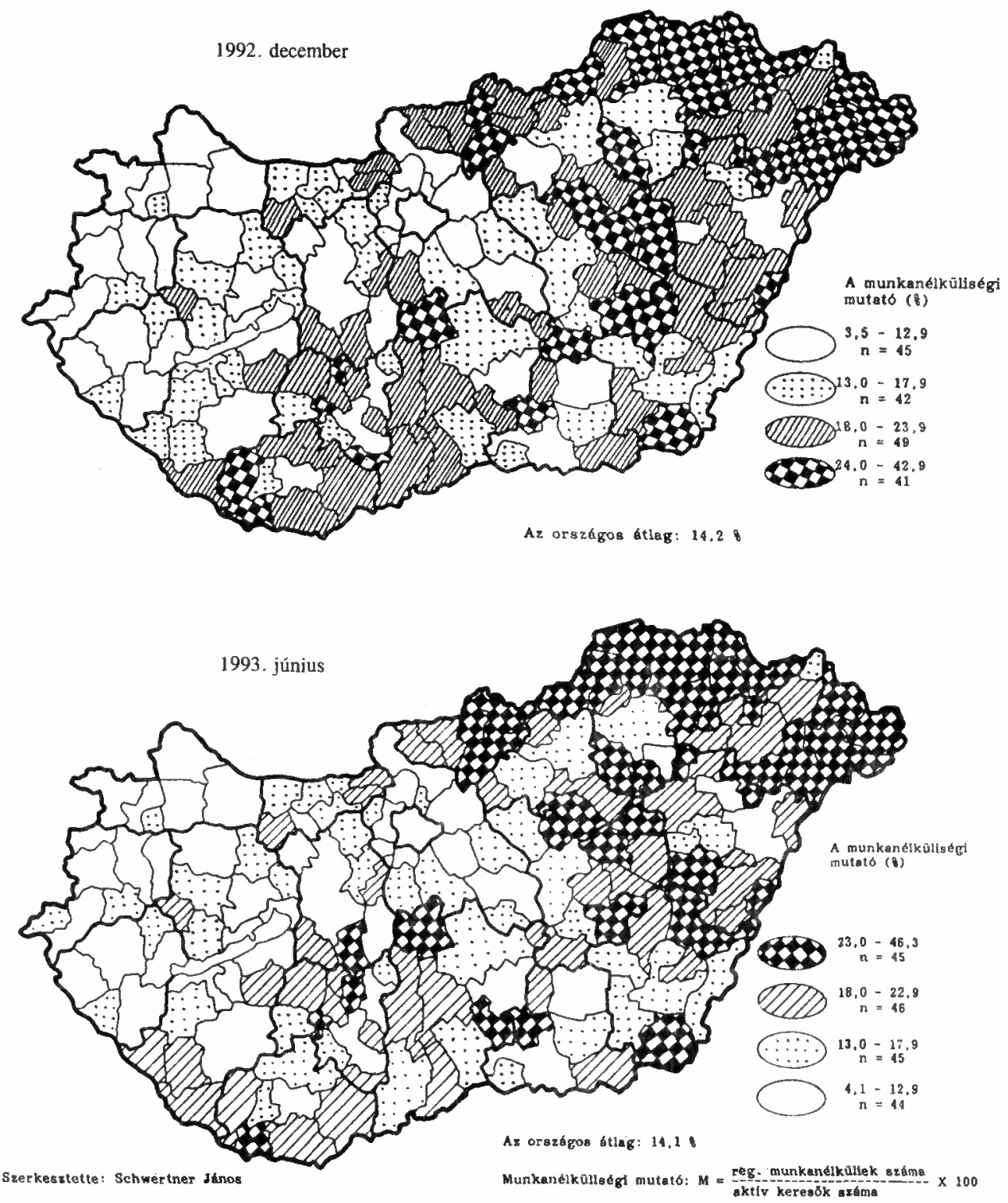


\section{TÁBLÁZAT}

A munkanélküliség mértéke régiók szerint, 1993. december

(The scales of unemployment by regions [December 1993])

\begin{tabular}{|c|c|c|c|c|c|}
\hline & $\begin{array}{l}\text { Gazdaságilag } \\
\text { aktív népes- } \\
\text { ség száma } \\
\text { 1993. I. }\end{array}$ & $\begin{array}{c}\text { Aktív } \\
\text { keresốk } \\
\text { száma } \\
1990 . \text { I. }\end{array}$ & $\begin{array}{l}\text { Regisztrált } \\
\text { munkanélkü- } \\
\text { liek száma } \\
\text { 1993. XII. }\end{array}$ & $\begin{array}{l}\text { Munkanél- } \\
\text { küliségi } \\
\text { ráta* } \\
\text { 1993. VI. }\end{array}$ & $\begin{array}{c}\text { Munkanél- } \\
\text { küliségi** } \\
\text { mutató } \\
\text { 1993. XII. }\end{array}$ \\
\hline Központ & 1496400 & 1383552 & 108229 & 7,2 & 7,8 \\
\hline $\begin{array}{l}\text { Nyugat- } \\
\text { Dunántúl }\end{array}$ & 349500 & 319476 & 30996 & 89 & 97 \\
\hline Közép-Dunántúl & 552800 & 514777 & 70209 & $\begin{array}{r}8,9 \\
12,7\end{array}$ & $\begin{array}{r}9,1 \\
13,6\end{array}$ \\
\hline Dél-Dunántúl & 632500 & 588713 & 78484 & 12,4 & 13,3 \\
\hline Dél-Alföld & 662600 & 617085 & 97139 & 14,7 & 15,7 \\
\hline Kelet- és & & & & & \\
\hline $\begin{array}{l}\text { Közép-Alföld } \\
\text { Észak- }\end{array}$ & 707300 & 653521 & 127767 & 18,1 & 19,6 \\
\hline Magyarország & 613900 & 576260 & 119226 & 19,4 & 20,7 \\
\hline Ország összesen & 5015000 & 4653384 & 632050 & 12,6 & 13,6 \\
\hline Budapest nélkül & 3998300 & 3710116 & 568514 & 14,2 & 15,3 \\
\hline
\end{tabular}

${ }^{*} \mathrm{R}=\frac{\text { regisztrált munkanélküli }}{\text { gazdaságilag aktív népesség }}$

${ }^{* *} \mathrm{M}=\frac{\text { regisztrált munkanélküli }}{\text { aktív keresõ }+\mathrm{m} \cdot \mathrm{n} \text {. a népszámlálás idején }}$

Forrás: KSH és OMK statisztika alapján számított mutatók.

\section{Társadalmi-gazdasági elmaradottság - munkanélküliség}

A munkanélküliség által leginkább sújtott térségek, körzetek jelentốs átfedésben vannak a több évtizede már ismert és a társadalmi, valamint gazdasági indikátorok alapján bizonyítottan elmaradottnak számító területekkel. A hazai munkanélküliség a nyugat-európai országok munkanélküliségétôl a kiváltó okok tekintetében jelentôsen eltér, mivel nálunk komoly erōfeszítések árán sem lehet a klasszikus értelemben vett ipari depressziós térséget találni (Fazekas K. 1993). Hazai ipari depressziós térségeink is kedvezôtlen foglalkoztatási helyzetüket nagyobb részt az elmaradott infrastruktúrának és a vállalkozások alacsony számának köszönhetik. Ezzel szemben a kedvezô humán feltételekkel, infrastruktúrával, nagyobb számú vállalkozással rendelkezô munkaerôpiaci körzetek munkanélkülisége az országos átlagnál kedvezöbb képet mutat (Enyedi Gy. 1993). A társadalmi-gazdasági szempontból elmaradott térségek lehatárolásánál az érintett települések $70 \%$-a olyan munkaerôpiaci körzethez tartozik, ahol a munkanélküliség mértéke másfélszeresen meghaladja az országos munkanélküliségi szintet. 


\section{A területi stabilitás}

A munkanélküliség ismert területi különbségei munkaerôpiaci szinten gyakorlatilag változatlanok (Schwertner J. 1992). A munkanélküliség szempontjából legkedvezốtlenebb helyzetũ munkaerốpiaci körzetek 1993-ban szinte kivétel nélkül megegyeznek a két évvel korábbiakkal (2. ábra).

Az 1993-ban a munkanélküliségi mutató szerinti megoszlás elsố quartilisébe kerülố 45 munkaerôpiaci vonzáskörzet közül 37 körzet 1992-ben, valamint 1991-ben is az alsó quartilisbe tartozott. A Dél-Dunántúl területérốl mindössze három munkaerốpiaci körzet (Sellye, Nagydorog, Hõgyész) állomásozik tartósan az alsó negyedben. Hasonló a helyzet a legkedvezőbb munkaerôpiaci körzetek esetében is. A munkanélküliség abszolút értéke körzetenként változott, de a térségek relatív helyzete mozdulatlan, ezzel is jelezve, hogy a hazai munkanélküliség mélyben gyökerezõ okai rövid távon nehezen változtathatók. 1990 és 1993 között a munkanélküliek régiók szerinti elhelyezkedésében sem történtek jelentôs változások (6. táblázat).

\section{TÁBLÁZAT}

A munkanélküliek megoszlása régiók szerint, \% (1993. júniusi állapot)

(Breakdown of the unemployed by regions, \% [(June 1993])

\begin{tabular}{|c|c|c|c|c|}
\hline Terület & 1990 & 1991 & 1992 & 1993 \\
\hline $\begin{array}{l}\text { Központ } \\
\text { (Budapest, Pest megye) }\end{array}$ & 7,3 & 11,8 & 16,3 & 17,8 \\
\hline $\begin{array}{l}\text { Nyugat-Dunántúl } \\
\text { (Gyôr-Moson-Sopron, Vas) }\end{array}$ & 3,3 & 3.9 & 4,8 & 4,8 \\
\hline $\begin{array}{l}\text { Közép-Dunántúl } \\
\text { (Fejér, Komárom-Esztergom, Veszprém) }\end{array}$ & 8,6 & 9,3 & $i 1,2$ & 11,0 \\
\hline $\begin{array}{l}\text { Dél-Dunántúl } \\
\text { (Baranya, Somogy, Tolna, Zala) }\end{array}$ & 14,5 & 14,0 & 11,9 & 12,1 \\
\hline $\begin{array}{l}\text { Dél-Alföld } \\
\text { (Bács-Kiskun, Békés, Csongrád) }\end{array}$ & 14,4 & 16,4 & 15.7 & 15,5 \\
\hline $\begin{array}{l}\text { Kelet- és Közép-Alföld } \\
\text { (Szabolcs-Szatmár-Bereg, Hajdú-Bihar. } \\
\text { Jász-Nagykun-Szolnok) }\end{array}$ & 22,3 & 23,1 & 20,4 & 20,3 \\
\hline $\begin{array}{l}\text { Észak-Magyarország } \\
\text { (Borsod-Abaúj-Zemplén, Heves, Nógrád) }\end{array}$ & 29,6 & 21,5 & 19,7 & 18,5 \\
\hline Ország összesen: & 100,0 & 100,0 & 100,0 & 100,0 \\
\hline
\end{tabular}

Forrás: OMK statisztika alapján számítva. 

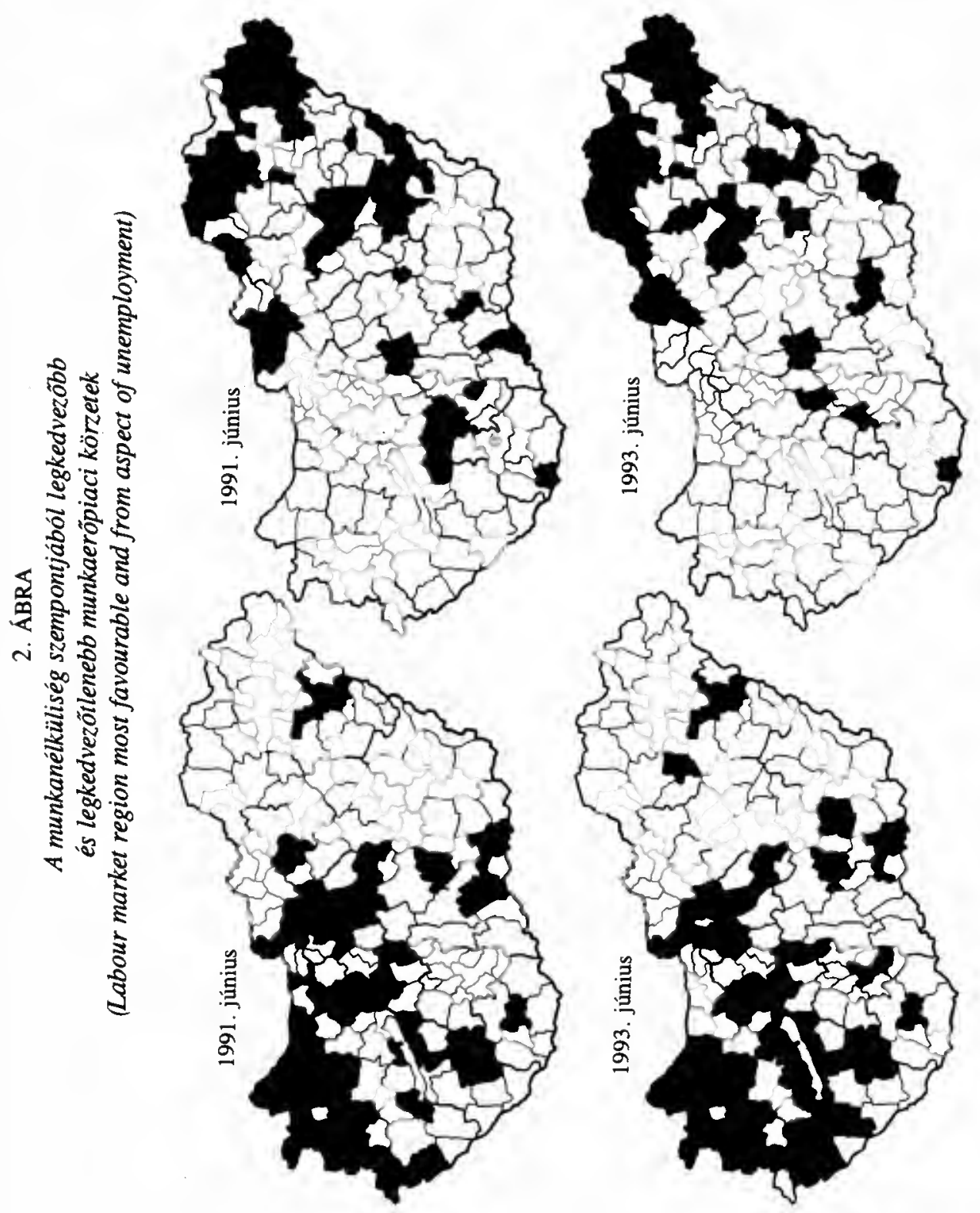


\section{A munkanélküliség mint diffúziós jelenség}

Amennyiben a hazai munkanélküliség döntõen közgazdaságilag leírható okokra lenne visszavezethetô, akkor nehezen lenne elképzelhetô, hogy a munkaerôpiaci körzetek magas munkanélkülisége terjedési jelenségként viselkedik. A szomszédsági kapcsolatok ilyen nagyfokú szerepének ellentmond az elmúlt évtizedek gazdaságfejlódése, a helyi gazdaság, a helyi piac hiánya.

A Dél-Dunántúl munkaerốpiaci vonzáskörzeteinek jellemzésére, a munkanélküliség növekedésének bemutatására az alábbi megközelítést alkalmaztuk. Körzetenként vizsgáltuk a regisztrált munkanélküliek és az aktív keresôk (az 1990-ben a népszámlálás idején magukat munkanélkülinek, illetve elsô ízben elhelyezkedni nem tudónak minôsítốket összevontuk az aktív keresốk számával) viszonyszámát 1990. decembere és 1993. decembere között.

Azokat a körzeteket, amelyek egy-egy negyedévben elérték az általunk megadott értéket, külön megjelöltük (7. táblázat). A Dunántúlon elsốként két Tolna megyei körzet (Nagydorog, Hógyész) érte el a kiválasztott 10\%-os munkanélküliségi mutatót. ${ }^{4} 1991$. ószén további hét (munkaerôpiaci) körzet érte el a kritikus szintet a Dél-Dunántúl keleti peremén. Ekkor már Tolna megye öt körzete, Baranya megye három körzete és Somogy

\section{TÁBLÁZAT}

A 10\%-os munkanélküliségi szintet elért körzetek

(Regions that have reached $10 \%$ unemployment level)

\begin{aligned} \hline \multicolumn{1}{c}{ Idốpont } & \multicolumn{1}{c}{ Körzetek neve } \\ \hline 1991. II. negyedév & Nagydorog, Hógyész (2) \\ III. negyedév & $\begin{array}{l}\text { Mohács, Sellye, Szigetvár, Tab, Tamási, Simontornya, Gyönk (7) } \\ \text { Komló, Siklós, Barcs, Marcali, Nagyatád, Boglárlelle, } \\ \text { Dunaföldvár, Tolna, Bátaszék, Zalaszentgrót, Letenye (11) }\end{array} \\ &$ Szentlốrinc, Csurgó, Bonyhád, Dombóvár, Szekszárd (5) \\ 1992. I. negyedév & - \\ II. negyedév & Nagykanizsa (1) \\ III. negyedév & Lenti (1) \\ IV. negyedév & Kaposvár, Zalaegerszeg (2) \\ 1993. I. negyedév & - \\ II. negyedév & - \\ III. negyedév & Siófok (1) \\ IV. negyedév & \end{aligned}

A 10\%-os munkanélküliségi szintet el nem érõ körzetek

Keszthely, Paks, Pécs 
megye tabi térsége lépte túl a 10\%-os küszöböt (8. táblázat). Az 1991-es év utolsó hónapjaiban országosan és a Dél-Dunántúlon is meglendült a munkanélküliek száma, ezzel újabb tizenegy körzet, ezúttal már a Zala megyei Letenye és Zalaszentgrót is elérte a kritikus értéket.

Gyakorlatilag az 1992. év elején a dél-dunántúli munkaerôpiaci körzetek kétharmada már túljutott a munkanélküliség $10 \%$-os szintjén, s az elsőként belépô munkaerôpiaci vonzáskörzetek (Nagydorog, Hôgyész) átlépték a 20\%-os munkanélküliségi értéket.

Összevetve az országos folyamatokkal, a Dél-Dunântúlon egészében kettô-négy hónappal később jelentkezett a munkanélküliségnek - az általunk kiválasztott mértékũ hulláma, de a régión belül jelentôs, mondhatni országrésznyi különbségek vannak. Jelenleg az országban összesen öt olyan munkaerốpiaci körzet van (Budapest, Sopron, Pécs, Paks, Keszthely), ahol a munkát keresốk aránya egyik hónapban sem érte el az aktív keresốk számának 10\%-át. Az öt körzetbốl három a Dél-Dunántúl három különbözổ megyéjében található.

A munkanélküliség szempontjából legkevésbé homogén Dél-Dunántúl mellett a vizsgálatot az ország teljes területére elvégezve megfigyelhetô, hogy az újonnan belépó körzetek jelentốs része szomszédos a 10\%-os munkanélküliségi szintet már elért körzetekkel, azaz egy terjedési jelenséggel állunk szemben. A térbeli diffúzió elméletének megalapozója, Hägerstrand (1967) megközelítését elfogadva a hazai munkanélküliség terjedése leírható az expanziós diffúzióval, azon belül a hierarchikus expanzióval, mivel a települések nagysága befolyásolja a vizsgált jelenség terjedését (Nikodémusz A. 1991). Meghatározott településtípusok között szorosabb és közvetlenebb lehet a jelenség terjedése, mint a közvetlen szomszédság felé. Az újonnan belépô, nem szomszédos körzetek szinte kivétel nélkül olyan munkaerõpiaci vonzáskörzetek, amelyek központja nem város, vagy fejlettsége alapján alig nevezhetố annak. Ezek a városi funkciókban hiányos körzetek minden megyében elsôként kerülnek a legmagasabb munkanélküliséggel rendelkezô körzetek közé.

A Dél-Dunántúlon ezt a kedvezôtlen hatást a fejlettebb és a munkanélküliség szempontjából kedvezõ helyzetũ körzetek pozitívan befolyásolhatják, hiszen a Dél-Dunántúl területe több potenciális növekedési pólussal is rendelkezik.

A három 10\%-os munkanélküliségi szint alatti körzet, kedvezô helyzetét eltérô okok magyarázzák:

- Paks: stabil foglalkoztatási viszonyok, ahol a relatív magas jövedelmekre épülö szolgáltatás nagyobbrészt fenn tudott maradni;

- Keszthely: fejlett idegenforgalmi szolgáltatás, ami csak részlegesen ér véget a nyári szezonnal (a Balaton egyetlen térsége, ahol a téli periódusban sem szaladt $10 \%$ fölé a munkanélküliség);

- Pécs: a fốváros mellett az egyetlen nagyváros, amely városi funkciójának sokszínũségével a kezelhetôség határán belül tudja tartani a munkanélküliség mértékét. 


\section{TÁBLÁZAT}

A munkanélküliségi mutató alakulása munkaerốpiaci körzetenként a Dél-Dunántúlon, \% (Change of the unemployment index by labour market regions in South Transdanubia, \%)

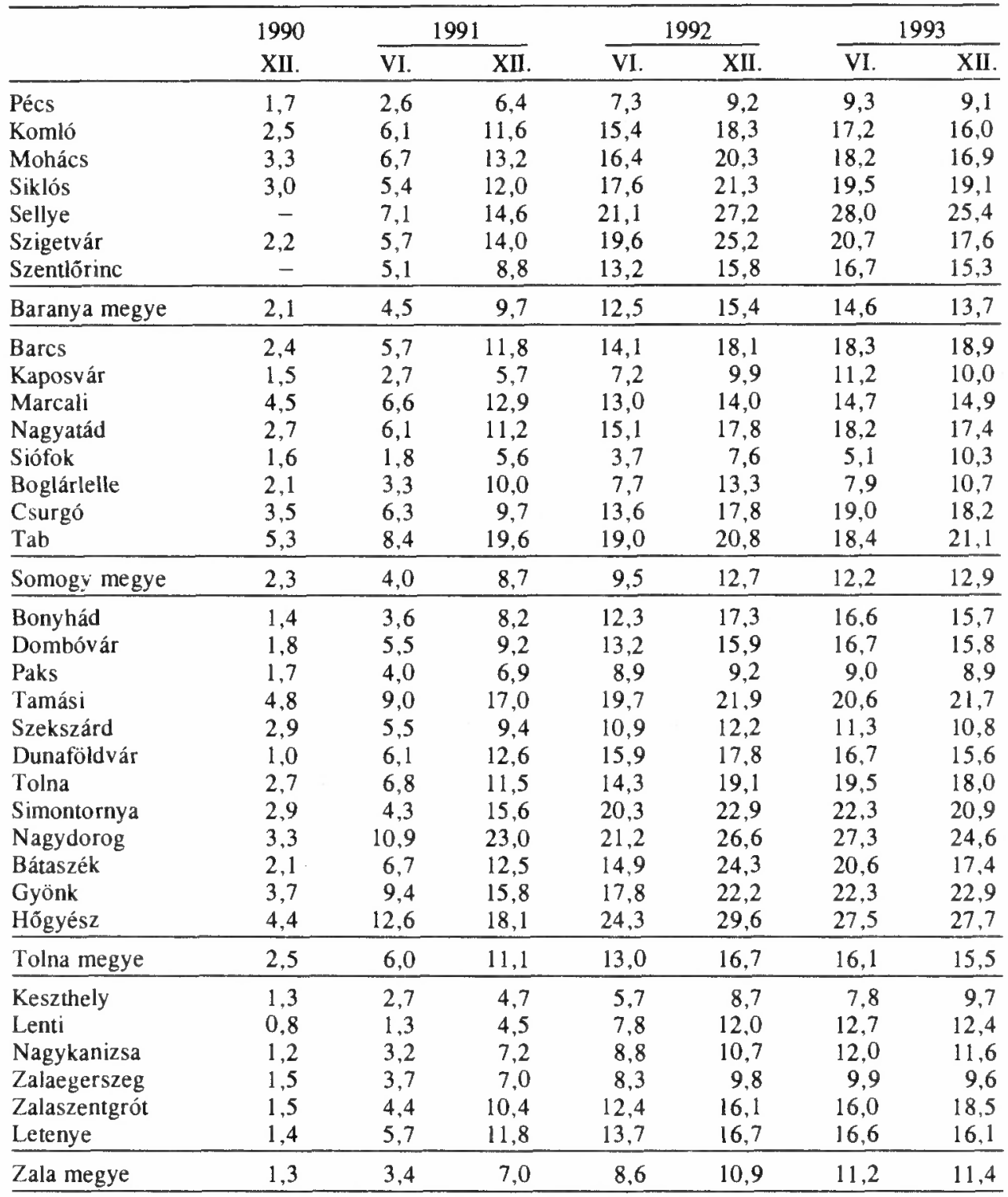

$\mathrm{M}=\frac{\text { regisztrált munkanélküli }}{\text { aktív keresốk }+ \text { munkanélküliek }+ \text { elsõ ízben elhelyezkedni kívánók }}$ 
A három munkaerôpiaci körzet három eltérố típusú munkaerốpiacot jelöl, egyúttal a munkanélküliség mérséklése, a jövố szempontjából három lehetséges fejlôdési pályát rajzol fel a még súlyos foglalkoztatási gondokkal küszködô körzetek elé.

Vizsgálatunk tanúsága szerint a Dél-Dunántúl a munkanélküliség terjedése szempontjából a legkevésbé homogén területe az országnak. Kedvezôtlen és kedvezô helyzetũ munkaerôpiaci körzetei között a munkanélküliség tekintetében , három évnyi" különbség van. Siófok, Keszthely, Paks, Pécs és részben Kaposvár, valamint Zalaegerszeg munkaerôpiaca az 1993. év végén is jobb helyzetben volt, mint a régió kedvezôtlenebb helyzetũ körzetei az 1991-es év közepén a munkanélküliség kezdetén.

\section{Falusi és városi munkanélküliség}

A területi különbségek másik meghatározó tényezõje a településtípusok, településnagyság-csoportok közötti fejlettségbeli különbség.

$\mathrm{Az}$ ország teljes népességének kisebb része, alig több mint 38\%-a élt az 1990 . évi népszámlálás idején községekben. A lakónépességnél kisebb arányt képviseltek a falun élổ aktív keresôk (36\%), részben a falusi térségek kedvezôtlenebb demográfiai összetétele, részben alacsonyabb aktivitási szintje miatt. Ennek ellenére a munkanélküliek közel fele a falusi települések lakỏi közül került ki. A településtípusok szerinti elsõ információink az 1991. év végérôl állnak rendelkezésre, amikor is a munkanélküliek $51 \%$-a volt falusi lakos. Arányuk fokozatosan mérséklődött az 1993. év végén nem érte el a $48 \%$-ot. A csökkenés elsôsorban a nagyvárosi településeken, részben a fôvárosban élõ munkanélküliek számának átlagot meghaladó dinamikájú növekedésébõl adódik.

A fentebb bemutatott tényezôk egyértelmũen jelzik, hogy a magyar gazdaságot és társadalmat ért azon kihívás, amit munkanélküliségnek nevezünk, a falun éló munkavállalókat erôteljesebben érintette, mint a városiakat. Részben a meglévố képzettségbeli és iskolázottsági különbségek miatt, részben azon oknál fogva, hogy a falusi munkavállalók fele (875 ezer fố) ingázó volt.

A falusi munkanélküliség mértéke a városokban ismertnek a másfélszerese. Megyénként azonban jelentôs eltéréseket tapasztalunk, míg Pest megyében a falun élök között a munkanélküliség mértéke az aktív keresôk számához viszonyítva csak 11,7\%-os, addig Szabolcs-Szatmár-Bereg megyében $29,5 \%$, és Borsod-Abaúj-Zemplén megyében $29,3 \%$ volt.

Országosan a falusi munkanélküliek száma elmarad a városiak mögött, ennek ellenére 12 megyében arányuk meghaladja az 50\%-ot. Legnagyobb arányt Szabolcs-SzatmárBereg $(66,6 \%)$, Pest $(65,6 \%)$, Tolna $(59,7 \%)$ és Heves $(59,5 \%)$ megyékben képviselnek. A településnagyság-csoportokat megyénként nyugat-keleti irányú földrajzi helyzetük alapján vizsgálva (3. ábra), jól érzékelhetô a földrajzi helyzet és a településnagyság egyaránt erôsítố hatása. 


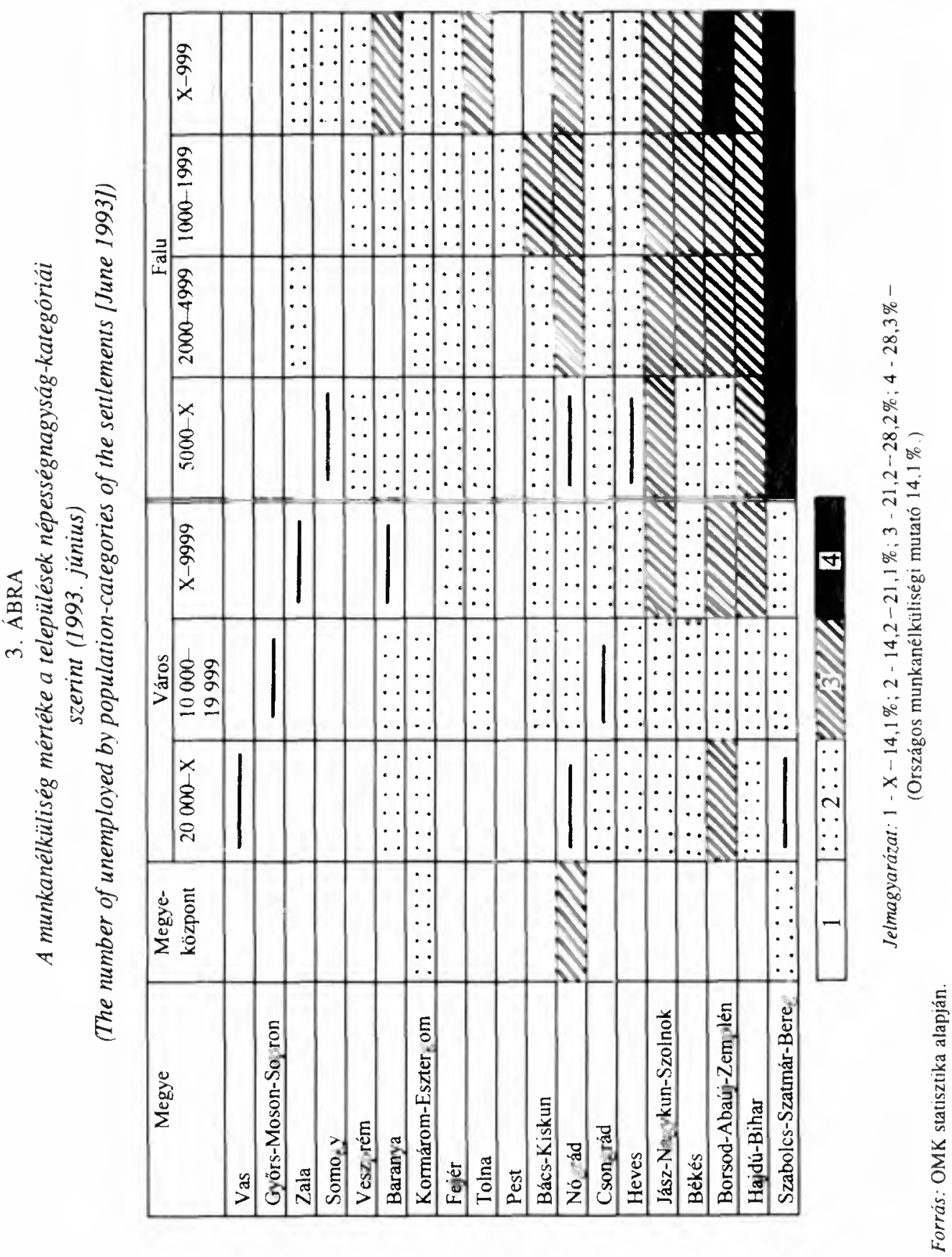




\section{Összegzés}

Az elmúlt négy év, a politikai és gazdasági rendszerváltás idôszaka drámai módon átalakította a munkaerốpiaci folyamatokat, pontosabban létrehozta a munkaerőpiacot. A kereslet-kínálat egyenlege 1990 nyarától országosan - 1990 végétôl a Dél-Dunántúl szintjén is - a kínálati oldal irányába mozdult el. Tömegével szũntek meg átmenetileg és véglegesen munkahelyek, emberek ezrei veszítették el korábban biztosnak vélt állásukat. A foglalkoztatottak számának 1,3 milliós csökkenése, a regisztrált munkanélküliek számának 700 ezer fô fölé történt emelkedése gyakorlatilag általános jelenséggé tette a munkanélküliséget. Csak 1993-ban közel egymillió ember kapott egy napnál hosszabb ideig munkanélküli segélyt vagy járadékot, 1990-tôl kezdôdôen pedig 1,3 millió fõ részesült passzív ellátásban. Gyakorlatilag egymillió háztartásban élt hosszabb-rövidebb ideig egy vagy több munkanélküli.

A korábbi egységes álmunkaerôpiac a munkanélküliség következtében széttöredezett, mert a munkanélküliség az ország minden térségét érinti, noha nem azonos mértékben. Azokon a munkaerópiacokon ahol nem rendült meg a termelés, ahol van fizetôképes kereslet a szolgáltatásokra, ahol fejlett városi funkciókkal találkozhatunk, ahol élénk a vállalkozási kedv, ott a munkanélküliség a kezelhetô értékek között maradt.

A Dél-Dunántúl egyes térségeiben már korán megjelent a magas munkanélküliség, míg más körzeteiben még jelenleg is alacsony szintũnek tekinthetố. A Dél-Dunántúlon egyszerre vannak jelen a munkaerôpiac pozitív és negatív változásai. Itt az átlagosnál gyorsabban élénkül a munkahelykínálat, de Zala és Somogy megye egyes térségeiben még jelentôss létszámleépítések várhatók. A Balatonhoz kapcsolódó idegenforgalom, valamint a mezốgazdasági termelés jelentôs munkavállalói kör számára a szezonális foglalkoztatást biztosítja. Ma még nehéz megítélni a szezonális foglalkoztatás következményeit, de tagadhatatlan, hogy a Dél-Dunántúlon ezrek számára ez lesz az egyetlen foglalkoztatási esély.

A Dél-Dunántúl területének nagyobb hányada távol esik a múködố tốke kedvenc befektetési területeitôl, ennek ellenére az elmúlt négy év bizonyította a régió életképességét. Kérdés, hogy a keletrốl nyugat felé az országon tovagördüló jelenség, a magas munkanélküliség veszít-e erejéből a Dél-Dunántúl nyugati megyéiben, vagy csak pillanatnyi megtorpanás idốszakát éljük. E kérdésre akkor tudnánk válaszolni, ha a makro munkaerôpiaci folyamatok változásának pontos irányát ismernénk. E válasz nélkül is érzékelhetố azonban, hogy 1993-tól a munkanélküliség új szakaszába léptünk. Az állástalanok korábbi gyors beáramlása helyett egy jellegében más típusú ,,parázsló" " munkanélküliséggel állunk szemben, ami egyszerre hordja magában a lángra lobbanás és a hamvadás lehetôségét. 


\section{Jegyzetek}

A munkanélküliségi ráta számításánál a nevezỏben a gazdaságilag aktív népesség szerepel, mivel azonban a megyénél alacsonyabb aggregációban ezt az adatot a KSH elōállítani nem képes, ezért a munkaerôpiaci körzetek vagy egyéb kisebb térségek esetén csak az aktiv keresők számát tudjuk használni. Az így kapott értéket következésképpen nem rátának, hanem munkanélküliségi mutatónak nevezzük. Ezek közé tartoznak: szabó, varrónơ, asztalos, mezōgazdasági traktoros, felszolgáló, textilkonfekcionáló, víz-, gáz-, olajvezeték kezelổ, vas- és fémszerkezet építõ, vendéglátóipari eladó, mezōgazdasági gépjármũvezetô, szarvasmarhagondozó, húsipari munkás, hentes, szakács, mezõgazdasági gépész, cipoôfelsőrész-készítō, vegyesbolti eladó, kazánfưtoõ, autóbuszvezetõ, szőllőtermesztô, gondozónõ, fakitermelō, erdômunvelô, mezõgazdasági mérnök, bő̃rdíszmūves, mezõgazdasági technikus, általános egészségügyi asszisztens, általános iskolai felsõ tagozatos tanár és általános iskolai tanár, tégla- és cserépgyártó, kesztyüs, kép- és elektroncsõgyántó.

3 A 90 -es évek recessziójának hatására az EK-országok munkanélküliségi rátája is emelkedik. A 10\%-os munkanélküliségi szinten túljutó Közösségben az aggodalmat nem is annyira a 17 milliós munkanélküli tömeg, mint annak összetétele váltja ki. A munkanélkülieknek ugyanis több mint a fele már egy évnél hosszabb ideje állástalan. Az elổrejelzések 1994-re a tartós munkanélküliek arányának további növekedését vetítik elénk.

4 A 10\%-os munkanélküliségi mutató kiválasztása tetszőleges volt. A munkanélküliség kezelése szempontjából ez az a szint, ami már jelentôsnek mondható, de feltételezéseink szerint még a kezelhetőség keretein belül található. Amennyiben a határt a 20\%-os munkanélküliségnél húznánk meg, a két körzet (Nagydorog. Hõgyész) szintén elsőként kerülne bele a kijelölt körbe.

\section{Irodalom}

Enyedi Gy. (szerk.) (1993) Társadalmi-területi egyenlỗtenségek. Közgazdasági és Jogi Könyvkiadó, Budapest.

Fazekas K. (1993) A munkanélküliség regionális különbségeinek okairól. Közgazdasági Szemle, 7-8. 694-712. 0 .

Hägerstrand, T. (1967) Innovation diffusion as a spatial proces. Chicago.

Lackó M. (1993) A magyar munkanélküliség nemzetközi összehasonlításban. Európa Fórum. 2. 28-46. o.

Lázár Gy. - Székely J. (1993) Helyzetkép a munkanélküliek ellátási rendsze réböl kikerültekrổl. Munkaügyi Szemle, 12.1-5. o.

Nemes Nagy J. (1985) Térbeli terjedési folyamatok és modelljeik. Földrajzi Értesítô, 4. 377-389.

Nemes Nagy J. (1993) Adalékok a térbeliség társadalmi magyarázóerejêhez. In: Enyedi Gy. (szerk.) Társadalmi-területi egyenlötlenségek. Közgazdasági és Jogi Könyvkiadó, Budapest, 23-37. o.

Nikodémusz A. (1991) A térbeli diffúzió problémája és alkalmazási lehetôsége. Földrajzi Értesítô, 1-2. 7-25. 0.

Rechnitzer J. (1993) Szétszakadás vagy felzárkózás. A térszerkezetet alakító innovációk. MTA RKK, Gyōr.

Schwertner J. (1992) A munkanélküliség regionális folyamatai. Comitatus, 12. 31-37. o.

Schwertner J. (1992) A munkaügyi szervezet, a munkaügyi tanácsok, valamint az önkormányzatok szerepe a helyi foglalkoztatáspolinika alakításában. Humánpolitikai Szemle, 7. $21-33$. o

Schwertner J. (1992) A munkanélküliség területi jellemzõi. Munkaügyi Szemile, 12. 27-33. o. 


\section{A CHANGING LABOUR MARKET}

\section{JÁNOS SCHWERTNER}

The past four years in Hungary was a period of political and economic systemic change, which dramatically transferred the labour market processes. More exactly it created a real labour market. The balance of demand and supply changed towards the supply side from the summer of 1990 in the nation, and from the end of 1990 in Southern Transdanubia. A huge number of jobs were eliminated temporarily or for ever. Thousands of employees lost jobs that had been thought to be certain before. The reasons for unemployment are various and have contributed during the past four years to the formation of unemployment of different intensities. We can summarise the reasons as follows:

- loss of COMECON markets

- reduction of the support system for agriculture

- impact of the recession in the developed countries

- narrowing of the inner market

- transformation of firms

- privatisation, new property structure

- transition of the geopolitical situation of Hungary

The result is the drop in the number of employees ( 1.3 million persons). The number of registered unemployed exceeded 700,000. This practically made unemployment a general phenomenon. In 1993, almost one million people were given unemployment benefits or payments for more than one day. Since the beginning of unemployment, a quarter of the active earners have received some form of unemployment care.

Simultaneously with the significant decline in employment, the rates of the three largest employment sectors changed. In the primary sector the rate of the employment decreased from 18 to $10 \%$, and in the secondary sector from $37 \%$ to $35 \%$, while the tertiary sector realised a growth from $45 \%$ to $55 \%$. The direction of the transition is favourable. It approaches the developed market economies, but the form and the speed of the changes are worrying.

The former uniform, false labour market, broke up as a consequence of unemployment. This is because unemployment touches all parts of the country, although not in the same measure. The labour markets where the production did not weaken, where there is a demand for services, where we can encounter developed urban functions, where the entrepreneurial willingness remained, have unemployment rates that are within acceptable limits. 
In the Southern Transdanubian region, situated in the South-Western part of the country, 78,000 unemployed are registered for the time being, the unemployment rate is practically the same as the national average (12.4\%).

In some regions of Southern Transdanubia unemployment appeared quickly, while it still can be considered low in some other areas. In Southern Transdanubia the positive and negative changes in the labour market are both present. The labour supply is activated faster than the average, but in some regions of Zala and Somogy counties serious reductions are still expected. The tourism connected with Lake Balaton, and agricultural production provide a great number of workers with seasonal employment. It is difficult to evaluate the consequences of seasonal employment yet, but it is undeniable that this will be the only chance of employment for thousands in Southern Transdanubia.

There are significant regional differences in the unemployment within Hungary, which do not leave Southern Transdanubia untouched, either. These regional differences can be summarised in five groups:

1) West-East dualism; in Hungary the unemployment of the Eastern areas is strikingly higher at all aggregational levels

2 ). The socially and economically underdeveloped areas practically coincide with the areas with high unemployment

3) During the past four years the circle of labour markets that are the most favourable and the most unfavourable for the unemployed has hardly changed

4) Unemployment rolled through the country as a negative diffusional phenomenon from the East to the West where the neighbourhood connections were more important than was predicted

5) The scales of unemployment is in an inverse proportion with the population size of the settlements. While the capital has a $6 \%$ unemployment, the same figure in the small villages of Southern Transdanubia is $20 \%$.

For all these reasons, in the treatment of domestc unemployment we cannot avoid the close cooperation of regional development and employment policy.

Translated by Zoltán Raffay 